\title{
AEROMAGNETIC AND GENERALIZED GEOLOGIC MAP OF SOUTHEASTERN PENNSYLVANIA \\ By
}

R. W. Bromery and Andrew Griscom

\author{
GEOPHYSICAL INVESTIGATIONS \\ MAP GP-577
}

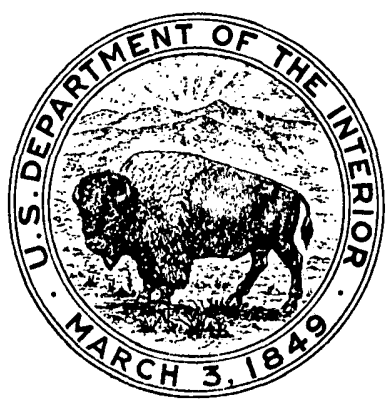

